\title{
Presidential Address Education and Social Development: Global Perspectives
}

\author{
Ali A. Abdi (University of Alberta)
}

\begin{abstract}
It is generally assumed that education leads to the well-being of societies and individuals, with the type of education intended here, usually representing the general formal systems of schooling that have been globalized throughout the world in the past 120 or so years. Clearly, such education, which replaced informal forms of schooling via the expansion of European colonialism, is not achieving social development for all. In this paper, it is contended that such platforms of learning are historically, culturally and linguistically decontextualizing, in especially current postcolonial countries, and as such, are not fully conducive to social development. It is therefore, suggested that new educational platforms be philosophically and epistemologically reconstructed, so they pragmatically fit the lived realities of different populations across the globe. In making these and related propositions, the works of such pragmatic educational thinkers as John Dewey, Paulo Freire and Julius Nyerere are selectively analyzed and referenced.
\end{abstract}

\section{Résumé}

En général, on considère que l'éducation mène au bien-être des sociétés et des individus. Ce type d'éducation est généralement représenté par le système formel de scolarisation, globalisé dans le monde entier depuis plus de 120 ans. Cette éducation qui a clairement remplacé les formes non formelles de scolarisation par le biais de l'expansion coloniale européenne, ne parvient pas à un développement social intégral. Cet article cherche à montrer que ces plateformes d'apprentissage, surtout celles des ex pays coloniaux, sont tout à fait décontextualisées du point de vue historique, culturel et linguistique, et qu'elles ne mènent pas à un développement social durable. Nous suggérons de ce fait de reconstruire ces plateformes du point de vue philosophique et épistémologique pour qu'elles soient vraiment à la taille des réalités quotidiennes des différentes populations à travers le monde. Pour cela, nous consulterons et analyserons de façon sélective les œuvres de quelques grands penseurs de l'éducation tels que John Dewey, Paulo Freire et Julius Nyerere.

\section{INTRODUCTION}

Education is intensely fundamental to human life. It is natural to social existence, it is primordial to the earliest formations of human groups, it is crucial for the survival realities of people, and it guides human advancement in the context of the prevalent bio-physical ecological connectivity and attached economic and political constructions that transitionally respond to the ongoing changes that are common to our realities. Indeed, education could be analyzed as an individual or societal project that is continuously created, recreated and refined so as to effectively respond to the changing communal situations that will be at times, unknown, unpredictable and even rationally unaccountable. It is with this in mind that education, with its valid global meaning and intentions, but for our purpose here, descriptively coming from the Latin word educatus (or educare), and which 
has been, as a concept and its attached intentions, popularized only in the past 500 years or so, could be selectively described as a response to something that has changed or is changing in our midst. What is changing can be personal, cultural, environmental or expansively aligned in the general cosmological terms. At the personal level, it is should be sensible to say that the first human engaged some kind of self-education to assure a basic instinct for survival; indeed, the first known pre-homo sapien hominids, of which the best known should be Lucy (or Dinkenesh in Amharic) should have devised, even with their very small brains, some way of understanding their environment about 3.3 million years ago. That first self-education by the first human should have been immediate and subjective, and since then, one could speak, at least theoretically, about the beginnings of experience-driven education. Needless to add that education is not limited to the domain of humans and their ancestors, but is also found in the animal kingdoms that share our planet. It is via education through experience that those who are live in the early 21st century, like myself, can make do with so many learning processes and outcomes that have been either successfully or unsuccessfully tried by others before them, and transmitted via different media of communication or coercion. Interestingly and for my purpose in this talk, the evolution of education seems to have some structural innateness that begs the backdrop or the visible destination of context. As such, education could be less effective if it is contextually detached.

For education to constructively achieve its objectives, therefore, it has to be contextually viable. Perhaps, a second example, after Lucy and early humans, would be how babies learn before and after they are born. If babies are already interacting with the world of their mother while they are still in the womb (Thomas, 2009), then again, educational processes are more expansive and more immediate than we thought. And again, for both antepartum and postpartum periods, the learning continuum is contextual, informal, and could be haphazardly achieved based on a world of guesses, imaginations and hit-andmiss platforms. Fortunately for the child, the parents have already done all of that, or have been taught not to do some of those. And while the road is still rough and unknown, the new learners will be protected from the plethora of fatal or quasi-fatal errors that could cripple their intentions, or so much worse, could even shorten their lives. Again, it is the context, the prevalent socio-cultural environment that determines what is chosen as a mini system of education and how it is used. Indeed, these early learning possibilities could also be described as early cultural formations that shape the project of fitting into the new context. And while I am not fully advancing the radical lines of behaviourism (in the Watsonian sense, see Ozmon and Craver, 1998), I can partially ascertain the 
quasi-organized attempt to deliberately shape the world of the new learner. Sometimes, the trouble with these new formations is that while the socializers (parents, later household or neighbourhood playmates, and much later teachers and others) may all have a unique project for the learner, in most cases, all these instructors will try to mould the new physically solitary person to fit their own solitary categorizations of some singular learning arrangements, which are, again, contextually socio-cultural. In most cases, therefore, we could see that all educational possibilities are heavily marked by those agents that are involved in their design, implementation and continuation. And it is from this biosocial location and its attached human-action realities that the world of education and its social development capacities or lack thereof, emanate from.

\section{GENERAL TYPES OF EDUCATION}

As Ghosh (1995) noted, there are generally three streams of education that are common to contemporary societies, which include formal education, informal education and non-formal education. Among these, the most institutionally ubiquitous one is formal education, which speaks about institutionalized systems of learning that result from political and economic pooling effects that are mostly publicly but also privately funded, and that are age-specific, certificate and promotion bound, and justified on the basis of specific so-called graduation requirements that formally release the learner from certain grade based conditionalities, so they can move to the next stage of learning. In looking at this type of education, it may not be difficult to see the restrictedness of its dispensation and availability, and how at the end of the day, it is a project of competition that looks for, and always finds winners and losers. Interestingly, the mass based form of this type of education, which is what we have all over the world today, is not as old as many think; it is about 120 years old and was proceeded by educational dispensations that took place in different forums with diverse but limited class-based determinants and results. Interestingly, the expansive development of current structures of formal education, which are, byand-large, of European construction, cannot be detached from 'new' social formations that took place since the advent of the age of European hegemony, which according to Janet Abu-Lughod (1991), may be circularized to the early $13^{\text {th }}$ century and beyond. This last statement should not disqualify the one preceding it; it is just that gradual formalizing of learning systems started early, indeed as early or even before Plato's Lyceum, but the massification is fairly new, and the main point here is that the sudden explosion of formal education is directly linked not only to the changing labour contexts brought about by the industrial revolution, but perhaps as much, by both the socio-political and 
scholastic formalizations of the perceived relationship between education and economic well-being.

Informal education on the other hand, should be the most expansive one at it continues from the pre-natal formations of the child's life into aspects of the life span, and takes place on uneven spatial, temporal and relational intersections of all lived contexts. As it is not formally structured and not determined by institutional sanctions, it tends to accord more freedom to the way people randomly learn, modify their connections with their situations, and indeed, the way they operationalize or de-emphasize accumulated knowledge in one form or another. This type of education is also more particular in the way it is constituted and practiced in different countries, regions and specific zones. Although they were not entirely random, pre-colonial traditional systems of education in Africa, Asia and the Americas are usually specified as having been informal in nature (Abdi, 2008; Semali, 2009). As has been pointed out by these and other writers (see also wa Thiongo, 1993, 2005; Achebe, 2000; Battiste, 2000; Lee, 2000; Mann, 2006), while these traditional systems of learning might not have been restricted to classroom situations, they nevertheless contained time and age bound expectations, even restrictions, that assured their relevance, timeliness and effectiveness with respect to the specific contexts they were designed for.

As Lee (2000) notes, in traditional China, for example, the Confucian idea of studying for one's sake was not a chance thing, but a socially established perspective that was not delinked from the overall expectations that enfranchise one's place in the general spaces they resided and in which they wanted to achieve and prosper. Despite these time tested realities, though, an important aim of the colonial project was to rescind, both theoretically and practically, the viability of such extensive and over millennia developed systems of learning that have sustained the lives of people (Nyerere, 1968; Rodney, 1974). The reasons for this onslaught need not detain our intentions here for too long: in order to undermine the cultural, and by random or planned extension, the ontological, educational and developmental capacities of people, the demeaning of their life systems and worldviews, and the implanting in their minds, that everything which represents the colonizer was superior, important and indispensable for their now existentially alienated lives, organized programs of de-historicizing and de-culturing the world of the natives were to be perforce affirmed. In speaking about the relationship of traditional informal systems of learning and social development, I can actually go back to the opening statements of this paper, and draw a direct line from the natural ways of learning, and that natural ways of learning should constitute small or extensively harnessable projects of social well-being that can be categorized, even measured in terms of one's positive or 
choice-deprived relationship with the environment that surrounds him or her. And it is the type of education that is inclusively produced by that environment, as Rodney (1974, p. 239) noted, that can represent the lives of people:

The following features of indigenous education can considered outstanding: its close links with social life, both in a material and spiritual sense; its collective nature; its many sidedness; and its progressive development in conformity with successive stages of physical, emotional and mental development of the child. There was no separation of education and [people's] productive activity.

This type of indigenous education is now marginalized, and with this marginalization, the learning systems in the world favour those for whom they have been created: Western societies and their public and private institutions. In terms of non-formal, one might see it occasionally lumped with informal education, and it should not be descriptively extraneous to see some cases where educational platforms are divided into formal and informal systems, with the non-formal somehow excluded. That may not be the best way to go, for nonformal education has specified intentions that are undertaken to address clearly established purposes. That is, non-formal education usually speaks about selectively designed, temporally bound, and rationally justified specialized seminars, courses and training projects that are implemented by specific organization with the general objective of improving certain skill sets that their workers need to either increase their productivity, or improve concerned working environments and relationships. These short term non-formal education programs are not specific to any particular organizational structure; they take place in both public and/or private institutions, and their outcomes could include the raising of productivity levels, and the teaching of new technologies or methodologies that should enhance the overall knowledge capacities of participants. While these may be the three most generalizable systems of learning, it is not impossible to think about, or even pragmatically consider the possibility of other learning trajectories that may not be descriptively or analytically located within the confines of these three types of education. As I talk about these in the classes I teach, I have encountered cases where a specific learning context experienced by one or more students could not actually fit into any of the above categories. As such, our points here should not be limiting in any way; on the contrary, these could be catalysts to seek different learning intersections that may increase the list of ascertainable educational types that could be located in diverse spaces and intersections of learning. In the following, I engage a non-detached foci on issues of development, the clash of educational contexts, the need to reconstruct new 
platforms of development education, and a reminder on the need to re-learn from leading pragmatic philosophers of education whose work has influenced my own thinking in educational and social development.

\section{LOCATING AND ANALYZING SOCIAL DEVELOPMENT}

In speaking about social development, it is fair to say what this should mean for me and perhaps for others. Technically for me, the terms social development could accord us a more comprehensive perspective than the old historically dry notion of development. As I was studying the global formations of the idea as well as the practices of development about a decade-and-half ago, and directly critiquing the problematic ideologies of development as a monolithic belief system that imposes its Eurocentric desires on the rest of the world, I also thought about the possible selective humanizations of the area. Here my intentions were not limited to disturb the dominant enlightenment induced characteristics of the case, although that may also be important, but mainly to descriptively and analytically bring it closer to the lived realities of the billions for whom it was prescribed as a remedy for the perceived ills of their underdevelopment. Needless to add that I am not claiming to have invented social development; as I found out later, others have used it before me, but it was still a non-referenced, instinctual outcome of my thinking processes that could be selectively and partially claimed via my scholarly writing and related analytical and critical domains. My own rationale for using the more inclusive 'social development', was based on my understanding that since all the categories of development that concerned my intentions then, i.e., the educational, the cultural, the political, the economic, as well as the technological and the emotional, were all responding to the needs of society, then they could all be comprehensively characterized as such. Despite this, though, and perhaps, a function of the still institutionalized use of the older genre, I still do use the two terms (development and social development) interchangeably, and will continue, pro-intuitively, doing the same here. But however these were conceptually constructed and regardless of who built them, there should be a number of early and ongoing questions about how development and underdevelopment should be defined, who defines social development, and whose life systems should be presented, indeed, derided as underdevelopment? What are the historical constructions of development and underdevelopment, and how are the dominant discourses in the area responsible for the construction of the now globally diffused categories of development, without taking into account the histories, the cultures as well the needs and aspirations of the to-be officially developed? These are important components of the story, and if nothing else, the hundreds of millions whose 
lives have been ravaged by the ills of development (Rahnema, 1997) should minimally re-read, even imaginatively, the false promise of a project that actually was continuously underdeveloping the disenfranchised, amazingly for the profit of the already highly endowed Northern hemisphere.

So before we analyze the role of current learning systems in ameliorating the lives of people, one need not minimize the conceptual foundations as well as the theoretical constructions of social development. While the official rhetoric of international development as applicable to all zones of the world might have started with the Fair Deal project advanced by former US President Harry Truman in 1948 (Black, 2002), one need not discount the effects of the falsely named European enlightenment on the belief that a dichotomous relationship existed between those who were achieving more in arts, sciences and systems of governance and those that were not progressing in those categories. The term 'false' is located in the reality that the nature as well as the outcomes of the enlightenment project, were not purely of European achievement, but were the results of the over millennia accumulated collective of human achievements that included the contributions of every continent and group. If, for example, one of the most important human inventions of all time is the use of iron, an item that was not only crucial for the scientific applications of the enlightenment derivative, but is also essential to the technological developments we observe today, with not many of all the gadgets and appliances, and unfortunately weapons we use today, being functional without the introduction of iron into both their old and new systematics, was actually first achieved in Africa by Africans (Jackson, 1970), then shouldn't Africans minimally claim a major platform in the so-called European enlightenment? We can of course, say the same about the seminal contributions of Asians in science, medicine, and of course, the same would apply to the great, enlightenment enriching inventions of Indigenous peoples in Pre-Columbus Americas including agricultural and irrigation systems, and extensive urban construction projects that were superior to anything known to Europeans as those invading Iberian hordes descended upon, and eventually destroyed those great civilizations (Mann, 2006).

As Sandra Harding (1998, 2008) suggested, it is high time that we recognize that all science, including the one that facilitated the enlightenment as multicultural and of collective human heritage. Here, Harding's and others' points in the case have been seemingly dismissed by dominant Northern metropolis historians who attributed almost all anno Domini achievements to the areas of their current and previous residences. Indeed, the spatial ownership of naming and who has that prerogative is crucial here. And as power was disindividualized in the way Foucault (1977) analyzed it, the capacity to name, 
assign and the concomitant certifications that result, ipso facto, fell under the monopoly of Western institutions and their governments. Indeed, with this already in place, and all development now realigned as unisource and monocultural, the project of European colonization sealed, at least for a long time, any corrective or rehabilitative procedures that might have cured the case from its wrong headedness and historical amnesia. As the onset of the colonial programs, one of the first ways to justify it was to deny the-to-be colonized populations any possibility to claim any viable social, educational, economic or technological achievements that might have diluted the announced purposes of the tragic practice. If Africans, Asians or others were allowed some claim to the human achievements that were hitherto harnessed, then the now benighted concoction of the 'mission civilisatrice' story (see Said, 1993) would not have the banner it was accorded, and which it successfully carried (only for the benefit of the colonizers) for so many decades. Among its outcomes, though, was the establishment of modernity as an enlightenment-driven project that should be good for all. Modernity, as an important philosophy and vehicle for international development, usually divides people into two categories: modern and traditional, As has been unilinearly expounded by some of its most important adherents, including the Americans Samuel Huntington and Walter Rostow, modernity was the last stage of human development that all were to aspire to.

Indeed, Rostow, in his well-known book, Stages of economic growth: a non-communist manifesto (1991 [1960]) was clear on who qualifies to be located in the program of modernity and who was not. In corroborating the stages of economic development he himself had invented, he wrote that "it is possible to identify all societies in their economic dimensions as lying within one of 5 stages: the traditional society; the pre-condition for take-off; the take-off; the drive to maturity; and the age of high mass consumption” (p. 2). In speaking about the traditional society, which was where colonized populations were arbitrarily assumed to be located in, Rostow (1991 [1960], p. 2) continued: "traditional society is one whose structure is developed within limited production functions; [that is] based on pre-Newtonian science and technology, and [that has] pre-Newtonian attitudes towards the physical world.” In expounding these ideas, it seems Rostow, had few important objectives. One of these, as the subtitle of his book indicates, was that he was ideologically responding to communism, which was becoming a mortal political and economic enemy for many in Western intellectual circles who deeply believed in both the moral and technical superiority of supposedly modernity-developed capitalism (even if some facts point otherwise), and its economic branch of laissez faire economics. By more or less following the scholarly freeways paved by Rostow, Huntington 
(1971), in his essay, 'The change to change: modernization, development and politics' continued what one might politely term a carte blanche scribbling about the lives of traditional societies, especially how they are at the mercy of nature, fundamentally backward, and therefore ripe to be rescued by modernity. Borrowing few things from Rostow and reframing the language with his own preferences, he speaks, inter alia, about the problem of time, traditional societies' problematic relationship with time, and the lack of production and management efficiencies that (note the hastened causal deployment) limit their forward movement.

As some of Huntingdon's later work has also shown (cf The clash of civilizations and the remaking of world order, 1996), which was called by the influential publication, Le Monde Diplomatique, the theoretical legitimization of American-led Western aggression against China and the world's Islamic cultures, this late Harvard social scientist, along with Walter Rostow, seems to have had a sizable mental space for grand theorizing, but in order to critically analyze the histories, cultures and other general sites of people's lives, and produce a new scholarship with some distinction of authenticity, one has to do more than just relating such simplistic stories about social development and the myriad ways it could affect and multi-directionally interact with the contexts of socially complex and intuitively subjective actors who know their locales, appreciate what works in those locales, and can ascertain what clusters of progress will work in those locales, undoubtedly more than the rest of us. That should be the desirable stuff of the social sciences and attached educational research, but at least in one important field in these two areas, i.e., social development, the assumptions seem to have outweighed practical scholarship, and perhaps as much as any other area, the study as well as the criticisms of development need a storm of counterhegemonic perspectives that are capable of responding to the falsehoods that have been constructed about colonized populations in all parts of our world.

\section{CLASH OF LEARNING PARADIGMS: THE PERFORCE 'NORTHERNIZING' OF THE SOUTH}

With many countries, especially in Africa and Asia, gaining their independence from colonialism from early to mid $20^{\text {th }}$ century, the banner of development, which really consisted of embracing modernity and looking like Europe, in economic, political and technological terms, was given a lot of space and currency in the postcolonial era. Again here, a cautionary insertion about the use of the term 'postcolonial' in a world where actually colonialism remained in most of these societies in more ways than has been accounted for here: it is intended to indicate a political understanding that eventually did not meet its objectives, and 
as such is used arbitrarily but with desired temporal convenience in this writing. With independence, one of the main tools that were identified as a central vehicle for national development was education, or formal education which was then based on structural and philosophical platforms that were constructed by colonialism. Undoubtedly, the 'development-through-education' chances missed here should be extensive and based on my understanding, this could be the main trajectory where things, in this and related domains, went quasi-horizontally wrong. After his release from 27 years of imprisonment and hard labour by the apartheid regime in South Africa, it was Nelson Mandela who said that just and equality oriented education can be the great engine of human development. Sans exception, the constitution of colonial education was the opposite of that. In earnest, it was anything but designed for the well-being of colonized populations. As Tanzania's first postcolonial President Julius Nyerere (1968) pointed out, the rescinding of African traditional learning systems and their replacement with counter-African ontologies imperial education was instrumental in destroying African ways of communal development, which later affirmed the mal-being of people.

Indeed, different societies can only thrive when local learning systems respond to the locally-identified needs of the community, which doesn't necessarily mean that all Western education systems are useless in today's postcolonial countries, for as I have emphasized previously (Abdi, 2002), we are now in a post-facto global environment where the world is collectively and interactively globalized, and where linguistic and technological needs already implanted could not be deracinated. Indeed, with almost all learning systems in the world now relatively responsive to the colonial restructuring of schooling, what I am calling for, is not a total educational revolution but some kind of effective reformation that brings in select and temporally functional perspectives from indigenous philosophies of education, ways of knowing and linguistic and cultural constructions of schooling. Factually, and regardless of what has changed in the past 200 years, Nyerere (1968, p. 268) was right when he wrote that "educational systems in the world have to be different because the societies providing them are different, and because education, whether formal or informal has a purpose." Let us selectively call this purpose the social well-being of dadka adduunka ku nool oo dhan (all people in the world). In simple terms, this should be what the majority of people want, and so much education which still purely tows the line of colonialism is irrelevant for the well being of the hundreds of millions of earth's inhabitants.

Interestingly, the role of colonial education did not limit itself, as all colonial programs proved to be, to the rescinding, in many cases the outright 
criminalization (see wa Thiongo, 1986, 1993), of Indigenous people's learning, pedagogies and epistemologies. It also, quite successfully, aimed for the mental colonization of its recipients to the extent where one's history, culture and languages became shameful and unworthy practices that were to be avoided. In some of the most brilliant discursive formations that has analytically responded to these realities, Frantz Fanon who, in his masterpiece, Black skin, white masks (2008 [1967]) clinically analyzed what happens to people when they internalize extensive doses of subjectively demeaning existentialities that relegate their personae and origins to de-historicized subterfuges that are species-wise, tantamount, to the dangerously dehumanizable. In simple terms, they could surrender their agency, would want to unbecome, and see their oppressor as representing all the normative categories they should aspire for (for related analysis, see Memmi, 1991). And it doesn't stop there; with its far-sightedness, colonialism also knew that in order for these colonies to always serve the colonizer (hence, the problématique of the postcolonial), then the mental deconstructions of select natives could actually perform, ad infinitum, the role of colonial education. One example I have used a few times in my writings that will still be very fit to be relayed here is Thomas Macaulay's 'Minute on Indian Education' directive, which due to Britain's impossible task to colonially educate all natives in India, emphasized the need to create a group of specially trained indigenous interpreters who should serve this role. He wrote:

It is impossible for us, with our limited means to attempt to educate the body of the people. [As such], we must at present form a class of people who may be interpreters between us and the millions whom we govern; a class of persons Indian in blood and colour, but English in taste, in opinions, in morals, and in intellect. To that class, we may leave it to refine the vernacular dialects of the country, to enrich those dialects with terms of science borrowed from the western nomenclature, and to render them by degrees fit vehicles for conveying knowledge to the great mass of the population (Macaulay, 1995 [1935]).

Macaulay's points are, sincerely for lack of better terms, interesting. Apparently for him and his colonialist cohorts, Indians were devoid of the right taste, right opinions, right morals and the right intellect, which is not really different from seeing some natural impurities in the basic, bio-mental systems of these natives, of which one must be cleansed. For the sake of observational peculiarity here, in present day India where hundreds of millions are subjected to the cruel practices of the socially dominant Caste system in supposedly developmentally delightful India, the physical and mental cruelties that are 
inhumanly released on the corporeal of the country's perennially victimized, are selectively justified on the impure tasks they perform, which in turn, and definitely with twisted rationalizations, supposedly makes them polluted, and in turn, affirms the continuities of discrimination and oppression. With this irresistible humanistic digression but descriptivo-topically extraneous addition (which, by the way, also affirms that the practice of oppression is not naturally particular to any group or continent), let me continue from above and ask those who are seeing the above quotation for the first time, perhaps to think about what has happened, with respect to these suggestions, in the Indian sub-continent since the early $20^{\text {th }}$ century. Many others who should have seen this multiple times might also do well to analyze, anew, these few lines in relation to India's class and elite formations, and how all things British are currently valued and appreciated. In other places such as Africa, the language issue was also important in assuring the triumph of the colonial education project. In so many cases where the multidimensional bond between language and its native speakers was broken, wa Thiongo (1993, p. 13) wrote: "[our] language, through images and symbols, gave us a unique view of the world.... Then I went to [colonial] primary school and the bond was broken. The language of my education was no longer the language of my culture - it was a foreign language of domination, alienation and disenfranchisement.”

As in many other parts of the colonized world, the few "lucky" who qualified for (what I have called in other contexts, those small non-normatively bright natives) and were chosen to join the few platoons of colonial interpreters have proven to the world that as things have shaped up since then, their admission into this exclusive but globally second-tier class (from colonial times and into the writing of this paper), has handsomely paid educational and social development dividends that the masses they were trained to control, never had a chance to reap. And to deepen the main perspective on education and social development, what did these Anglophonized or Francophonized (as in Senegal or Vietnam, for example) do with the colonial education they received? Did they reanalyze that, deconstruct it and reconstruct new platforms of learning that had liberatory prospects for the masses? No, they did not; in fact, one could say they were too smart to lessen the value of their exclusive club to massify, for example, the learning of English, French, or Spanish languages, and with that fact, their political, economic and new cultural powers were affirmed and remain intact as I am giving this talk. In addition, as Ngugi wa Thiongo (2005) noted, these processes of miseducation and de-linguicization were deployed to assure the durability of mental colonization, which is so much more difficult to overcome than the immediate pain of physical domination. 


\section{NEW PERSPECTIVES ON DEVELOPMENT EDUCATION}

In the preceding observations, I should have established a non-empirical but general understanding that relevant education leads to social development, or as I termed it in other times, human well-being. As such, we could talk about what we can call 'development education' which should be designed for, and established for the attainment of ameliorative livelihood possibilities for those who attain it. Here, and as I alluded to above, we are not disavowing contemporary possibilities of social development, for in these post-facto spaces of extensively globalized life systems, there is a viable convergence of people's needs wherever they may be, and with this affirming the induced materialist needs that have been implanted in the minds of people, the time we spend on any counter-development projects may not serve us well. Even some of the strongest and most comprehensive post-development theses such as those propagated by, among others, Leys (1996), Rahnema and Bowtree (1997), and de Rivero (2002), which are not uniform in their recommendations to find a different trajectory for global human well-being, may actually have more analytical appeal than practical applications. And the analysis is, of course, important, for it minimally accords us a wider understanding of where things sont allées mal. But later in the day, more people will still tell us that they want development as it is known in Canada, the US and Japan, and as it is emerging in China and Korea, hence, the need to examine education as a potential tool for social development. The main question then, is, can there be some form of development education that we can speak about in the global context?

Technically, it may not sound very pragmatic to talk a global development education, for the education that helped Canada and Japan to be where they are today in the developmental ladder, may not serve the interests of Nigerians, Bangladeshis, or Nicaraguans. As such, the selective use of development education is intended to advance the dominant line of analyses that have been adopted in this paper. That is, a focus on spaces of life that have been colonized by European powers, and later by Euro-American imperialism. To be sure, therefore, the types of learning programs that should appeal to those countries that are aspiring for possibilities of social development should be first and foremost, historically and culturally inclusive. As UNESCO correctly points out, it is culture that forms both the color as well as the texture of social development. Indeed, when one looks at why current systems of education are working so well in some countries and not in others, one can clearly see whose culture this education advances. Beyond the physical locations of schooling, the main items on the educational plate are policies, languages, personal 
relationships, and general cultural and social capitals. Contemporary systems of schooling are of European history, culture and construction; as such, they apparently serve well all those whose socio-political (with economic rationalizations) policies, languages and cultures are reflected in that education. And to anticipate a potential question with respect to Asian countries that may be doing well or relatively well (e.g. Japan, Korea, Malaysia, Singapore, and lately China), one must understand that in most of these states, there was a deliberate project of re-culturing postcolonial education systems, and establishing new learning programs that did not alienate the concerned school populations (Kwapong, 1994).

In other spaces where this did not happen (e.g. Africa), the failure of the development program was not only based on the uni-directional way the thing was exported, although that was important (Ake, 2005), but more so by the fact that post-independence learning programs were not philosophically or epistemologically reconstructed to fit local life systems. As I indicated above, dehistoricizing and de-culturing educational programs is tantamount to deontologizing people's realities, which, as Thierry Verhelst pointed out in his excellent book, No life without roots (1991), cancels any development possibilities for the populations concerned. As such, regardless of the intensities of current globalizations and the extensive intermeshing of the life systems we are seeing today, there is still a viable space for reconstructing postcolonial educational systems in many parts of the world. In my understanding, these new possibilities, which should culminate in the re-historicizing, re-culturing and relinguicizing of these platforms of learning, should first start with extensive projects of recasting the philosophical and epistemological foundations of education. Every project of learning begins with philosophical considerations, and whether it is pronounced or not, achieves philosophical objectives. In the intervening space, though, the role as well as the function of the epistemological becomes crucial. As we know so well in Canada, the educational problems Aboriginal peoples are facing usually involve issues of philosophy, language, culture, and epistemologies (Battiste, 2008). If people's epistemological realities or ways of knowing (more comprehensively, theories of knowledge) are located counter the characteristics of the educational project, the overall learning enterprise could move from a potential platform for human well-being to an active intersection of underdevelopment and marginalization. Indeed, this is beyond the theoretical; we can see it in the contexts we teach, and we can take note (actually account for) the historical debris it left behind, not only in Aboriginal Canada, but as well in the hinterlands of Africa, and undoubtedly, on the highlands of Latin America. It is therefore, this pragmatism that should guide 
the new investigations current systems of learning should be subjected to, and it should be from here, that one must realize that those educational thinkers whose work we reference, perhaps more than others (for my purpose here, John Dewey, Paulo Freire and Julius Nyerere), were more than willing to appreciate the need to critically read the historical and cultural notations of education, and call for the pronto contextualization of all learning spaces.

\section{DEVELOPMENT EDUCATION: HEEDING THE CALLS OF DEWEY, FREIRE AND NYERERE}

John Dewey (1859-1952)

There are important reasons of why the two philosophers who have been called the most important educational thinkers in the $20^{\text {th }}$ century, i.e., John Dewey and Paulo Freire are also described as pragmatic philosophers of education (Ozmon and Craver, 1998). Dewey lived both in the $19^{\text {th }}$ and $20^{\text {th }}$ centuries, and as such has been influenced by huge educational and technological shifts that have especially taken place at the turn of the latter. Even his theoretical and practical foci changed from earlier functional psychology inclinations and a lot of Hegelian idealism, with transactional philosophy and philosophy of education coloring more and more, his teaching and research output after he arrived at Teachers College, Columbia University in 1905. It was Dewey who said that all philosophy is a theory of education, which for me, represents, not only that general thought and analytical process must inform educational research, but as well, the open ended nature, minimally at the policy level, of learning formulations, implementations and evaluations. It also reflects Dewey's open mindedness, in terms of how we do education, a perspective that can be clearly gleaned from his early writings including, The school and society (1956), and two of his most influential works, Democracy and education (1966) and Experience and education (1963). In all these works, Dewey's pragmatism shines; he repeatedly asks us to critically respond to the specific requirements posed by relevant schooling contexts and social relations, and seeks analytical trajectories that are not ideological, but philosophically practical. Indeed, those who studied him should uniformly describe him as seminal thinker who was ahead of his time, and who called for systems of learning that were representative of the histories as well as the lives of the peoples concerned.

By interested, critical hindsight, therefore, one can see that regardless of the racially problematic situation of mid- $20^{\text {th }}$ century America where segregation and Jim Crow laws were being practiced in many parts of the US (even if Dewey was mostly working in areas that have not been the worst affected), the way he expounded his ideas and experiments, has undoubtedly, helped craft the thinking 
where learners can seek ways to relate to their environments of schooling. Many decades before others have spoken about it, it was Dewey who emphasized how we needed to 'pragmatize' the transitional home-school space for learners, so schooling and its different components could be for the child, realistically quantifiable, pedagogically tangible and socio-culturally knowable. Technically, therefore, Dewey was not unaware of the importance of identity and culture in educational settings, issues that have been later popularized in the multicultural education and critical pedagogy areas. It is on the basis of these and related educational projects undertaken by Dewey that should qualify him to help us locate and achieve the inclusive type of development education we are seeking in this discussion. Indeed, With Dewey's later works, so much informing the requisites for contextualized domains of learning and teaching, the multidirectional comfort zone of education that should be established between learners and spaces of schooling has to be of utmost importance for the attainment of the 'right' development education. In Dewey's understanding, it was not the students who were to adjust to fit the schooling character and structure, but the other way around; the system had to bend to the needs and the aspirations of the learner, which is exactly what we are seeking now and into the future.

\section{Paulo Freire (1921-1997)}

Following Dewey in temporal sequence, but not necessarily referencing his works directly, Paulo Reglus Neves Freire decided to see and study educational problems and prospects in their contexts. Indeed, one might also say that Freire was himself contextualized by the circumstances of his native Latin America. The history of Latin America has been described as one of the harshest colonial and postcolonial experiences for the non-elite members of these societies (Galeano, 1982; de Botton, 2002). As Galeano so powerfully describes the situation is his excellent work, The Open veins of Latin America: five centuries of the pillage of a continent (1982), among other seminal works, where after the enslavement as well as the deliberate destruction Indigenous peoples (see also Crocker, 2001), followed by the enslavement of Africans, whatever come out of that continent was also systematically exploited and indirectly colonized by subsequent American regimes that many times installed and supported cruel, supposedly postcolonial dictators who continued from where the Spanish and the Portuguese left off. It was through this reality that across-the-centuries, Latin American countries collectively had some of the most unequal societies in the world. As Klasen and Nowak-Lehmann (2009, p. 1) note, 'Latin America continues to have the dubious distinction of having the highest income inequality in the world, as measured by the gini coefficient, [and] using other measures, or 
other dimensions of inequality (e.g., assets) would yield similar results.” It is via this heavily constructed and persistent inequality that tiny ethnic or family elites owned the land and almost everything else at the expense of almost everybody. It was also here, where what remained of the Indigenous and African populations were relegated to subterranean corners of underdevelopment and racial discrimination. As this internal colonization continued, it was no wonder that the domestically colonized involuntarily absorbed so much onto-existential inferiorizations that were inscribed upon their being. And with that, the conventional education was no remedy for the clustered learning and development ills that have befallen upon this large underclass.

It was in the intersections of these historical and contemporary realities, therefore, that Paulo Freire saw the failure of conventional education to transform the lives of the perennially marginalized. Here, those whose existentialities have been branded with so much deprivation and exploitation apparently developed a sense of naturalness about their situations. As Albert Memmi (1991) spoke about in his book, The colonizer and the colonized, (with select Hegelian attachments), the dual processes of dehumanization that are at the core of all colonial projects eventually create a reality where the two creatures of the story (i.e., the colonizer and colonized) cooperate on the continuities of colonialism, thus engendering an extra-ontological and, undoubtedly, extra-anthropoid space where oppression is almost normalized, and seemingly perpetuated by the actions of the previously opposing actors. To deal with this naturalization of oppression, therefore, Freire saw the need for what we might term as organized consciousness raising among the under-underclass of Latin America and later, elsewhere in the world. Freire called this consciousness raising project conscietizaçäo (roughly translated, though not fully correctly, as conscientization). In choosing this project as the starting point for re-educating the marginalized in ways that are familiar to them, Freire was using the pragmatics of the local context, and was true to the essential formations of informal learning possibilities (as opposed to conventional structures of schooling that perpetuated inequities). As discussed in his seminal work, Pedagogy of the oppressed (2000 [1970]), the project of conscientizaçäo involved different stages of understanding the problems the community is facing; ascertaining ways of dealing with those problem, and via reflection and inclusive action, aim to achieve the needed social well-being. This is indeed, where Freire's praxis, or explaining and theorizing to achieve practical transformations, would function, in a parallel format, with the processes of conscientization that are desired. Due to the uneducated, illiteracy status of the concerned populations, though, Freire's praxis also included ways of fast-tracking the learning process, hence his focus on adult education programs that should go beyond mechanical 
literacy, and that allowed people to both read the word and the world. In sum, therefore, Freire's was not an ideological program of learning, but one informed by local conditions-induced critical consciousness (see Freire, 1985), that would be undertaken via realities created by the actual context. In his posthumously published work, Pedagogy of indignation (2004), Freire searches deeper into the suppressed existentialities of the learner vis-à-vis the social edifice of schooling, critical citizenship rights, and the construction of possibilities of resistance to expand the space of the possible. At its core and with all its attachments, Freire's was a pedagogical project that was historically and dialogically contextualizing, and that sought the 'righting' of educational wrongs for the practical benefit of all.

\section{Julius Nyerere (1922-1999)}

The third pragmatic thinker of education who should be firmly located in the tradition of educating people from, and within contexts in which they live, is the philosopher-statesman, Julius Kambarage Nyerere, who was Tanzania’s first postcolonial President. As Freire and undoubtedly Dewey, Nyerere was also greatly influenced by the environment in which he was born and grew up. As a young boy, being raised in Northern, colonial Tanzania in the 1920s, Nyerere was first exposed to the still functional, if already de-institutionalized, informal systems of learning that were found in his surroundings. He absorbed the culture of his people, learned the esteemed place of elders in the community, and understood how the collective interests as well as the needs of all members of society would take precedence over the demands of the individual. As was common in all colonial situations in Africa and elsewhere, this early informal education was to clash later with European ways of learning and teaching that, as mentioned above, first and foremost, demeaned and deliberately delinked the community from its epistemological and linguistic centres. Needless to add that with almost all economic venues of the now globally re-structured country in the hands of colonizers, anti-indigenous European education slowly became the sine qua none of employment and possibilities for personal advancement. When young Nyerere joined the formal education system, he was already a very focused, precocious child who excelled in his schooling assignments. Many years later, he will earn a Master's degree from Edinburgh University, and as the President of the nation, will have in his hands the political power to make the educational changes he envisioned.

For Nyerere, the project of education for development was to be rewritten from anew in postcolonial Tanzania. That, of course, was not an easy task as everything that concerned schooling was based on foreign philosophies, epistemologies and languages. Apparently, none of those discouraged Nyerere 
from becoming, perhaps the only African leader in the 1960s, to see the central problem of education: the reliance on foreigners' needs and the strategies as well as the priorities that were established by these. As should be gleaned from his oft-referenced essay 'Education for self-reliance' in his book, Freedom and socialism (1968), which was central to his Ujamaa (villagization) projects, exposing the dichotomous relationship between what Tanzanians needed for inclusive social development and what they inherited from imperial powers was very important for Nyerere, and that should have given him the support of his people. In this essay, he was clear on the need for primary contextualizations of the type of education that will work for Tanzania, which should be pragmatically different from that of societies where liberal democracy dictates the cardinal rights as well as the sins of the individual. In a later essay, 'Education never ends', he repeats some themes from those earlier writings:

This is what our educational system has to encourage. It has to foster the social goals of living together and working together for the common good. It has to prepare our young people to play a dynamic and constructive part in the development of a society in which all members share fairly in the good or bad fortune of the group, and in which progress is measured in terms of human well-being, not prestige buildings, cars, or other such things whether privately or publicly owned (Nyerere, 1979, p. 20).

In reading this passage, it is clear that he is reflecting the values of the African context where he grew up; he was not also unaware of what has been already implanted in the psyche of colonized populations. So the appeal of his statements will not be uniform. For better or worse, the bug of individualism, private ownership of everything including outer space, and the rhetoric of meritocracy have already become worldwide equal opportunity infectors. And a lot of people in Tanzania may tell Nyerere to live in the present and detach himself from the romanticism of supposedly idyllic, equal, 'all good', precolonial traditional Africa. What most of these should be misreading, though, is that waking up and living in the present simply means systems of learning that marginalize the overwhelming majority of the population, where tiny elites, in problematic collusion with foreign interests, enrich themselves and their families at the expense of the majority underclass, and education is not actually pragmatically located, but ideologically imposed, and as such is not for social development, but for individual interests and enrichments. As we wrote recently (Mhina and Abdi, 2009, p. 67), Nyerere's locally conceived, locally designed and locally responsive educational and social development policies, with ongoing 
policy and program re-structuring (which should be common to all such projects), would have undoubtedly, pragmatically yielded so much more for the people of Tanzania. And to answer the potential counter-point, perhaps we should ask every Tanzanian what they think of the case in post-Nyerere, early $20^{\text {th }}$ century Tanzania. Sin duda, the man his people dubbed Mwalimu (teacher) will score very high.

\section{FINAL REMARKS}

To conclude, it is clear that I have aimed for a wider angle to speak and analyze notions and practices of education and social development that may be attachable to many contexts of our world. I have tried to selectively provide some descriptions including a number of lines on different forms of education, which, although, they may not greatly appeal to those who are overwhelmingly analytical, should, nevertheless, explain things more contextually, and give us some ongoing situational understanding of the issues under consideration. Let me repeat, the context for me is the most important, and with colonial education and its continuities so decontextualized in relation to the histories, cultures, languages and overall beings of people, we have today, a reality where so much formal education that is dispensed around the world is not conducive to the well-being of populations across the globe. To change this, we need to reconstruct the philosophical and epistemological platforms of learning programs that have been previously designed, not for the well-being of concerned societies, but for the sustainability of colonialism and its affiliated schooling and social engineering projects. To overcome some of those problems, which have been actually exacerbated by the current schemes of globalization, we could heed the call of such pioneering educational thinkers as John Dewey, Paulo Freire and Julius Nyerere, who as pragmatic philosophers of learning and social development, have shown the way for the need to contextualize educational possibilities for the benefit of all stakeholders. With that Perhaps, we could envision some assurance in the case to the extent that we may even state our intentions with formulaic desire, as $\mathrm{E}=\mathrm{SD}$, or education surely leads to social development. 


\section{References}

Abdi, A.A. (2002). Postcolonial education in South Africa: problems and prospects for multicultural development. Journal of Postcolonial Education, 1(1), 9-26.

Abdi, A.A. (2008). Europe and African thought systems and philosophies of education: 're-culturing' the transtemporal discourses. Cultural Studies, 22(2), 309-327.

Abu-Lughod, J. (1991). Before European hegemony: the world system A.D. 1250-1350. Oxford: Oxford University Press.

Achebe, C. (2000). Home and exile. New York: Oxford University Press.

Ake, C. (2005). Democracy and development in Africa. Washington, DC: Brookings Institution.

Battiste, M. (2000). Reclaiming Indigenous voice and vision. Vancouver: UBC Press.

Battiste, M. (2008). The decolonization of Aboriginal education: dialogue, reflection and action in Canada. In P.

Dasen \& A. Akkari (Eds.), Educational theories and practices from the majority world. London: Sage, pp. 168-195.

Black, M. (2002). The no-nonsense guide to international development. Toronto: Between the Lines.

Crocker, M. (2001). Rivers of blood, rivers of gold. New York: Grove Press.

De Botton, A. (2002). The consolations of philosophy. New York: Vintage.

De Rivero, O. (2002). The myth of development: the non-viable economies of the 21st century. VHPS Distribution.

Dewey, J. (1956). Society and education. Chicago: University of Chicago Press.

Dewey, J. (1963). Experience and education. New York: Collier Books.

Dewey, J. (1966). Democracy and education. Free Press.

Fanon, F. (2008 [1967]). Black skin, white masks. New York: Grove Press.

Foucault, M. (1977). Discipline and punish: the birth of the prison. New York: Pantheon.

Freire, P. (1985). Education for critical consciousness. South Hadley, MA: Bergin \& Garvey.

Freire, P. (2000 [1970]). Pedagogy of the oppressed. New York: Continuum.

Freire, P. (2004). Pedagogy of indignation. Boulder, CO: Paradigm Publishers.

Galeano, E. (1982). The open veins of Latin America: five centuries of the pillage of a continent. New York: monthly Review Press.

Ghosh, R. (1995). Social change and education in Canada. Toronto: Harcourt.

Harding, S. (1998). Is science multicultural? Postcolonialisms, feminisms and epistemologies. Bloomington, IN: Indian University Press.

Harding, S. (2008). Sciences from below: feminisms, postcolonialities and modernities. Durham, NC: Duke University Press.

Huntington, S. (1971). The change to change: modernization, development and politics. Comparative Politics, 3(3), 283-322.

Huntington, S. (1996). The clash of civilization and the remaking of world order. New York: Simon \& Schuster. Jackson, J. (1970). Introduction to African civilizations. New York: University Books.

Klasen, S. \& Nowak-Lehmann, F. (2009). Poverty, inequality and policy in Latin America. Cambridge, MA: MIT Press.

Kwapong, A. (1994). Culture, development and democracy: role of intellectuals in Africa. In S. Soermadjan \& K. Thompson (Eds.), Culture, democracy and development: the role of the intellectual. New York: The United Nations University Press.

Lee, T. (2000). Traditional education in China. Boston: Brill

Leys, C. (1996). The rise and fall of development theory. Bloomington, IN: Indiana University Press.

Macaulay, T. (1995 [1935]). Minute on Indian education. In B. Ashcroft, G. Griffiths \& H. Tiffin (Eds.), The post-colonial studies reader. New York: Routledge, pp. 428-430.

Mann, C. (2006). 1491: New revelations of the Americas before Columbus. New York: Vintage.

Memmi, A. (1991). The colonizer and the colonized. Boston: Beacon Press.

Mhina, C. \& Abdi, A.A. (2009). Mwalimu's Mission: Julius Nyerere as (adult) educator and philosopher of community development. In A. Abdi \& D. Kapoor (Eds.), Global perspectives on adult education. New York: Palgrave Macmillan, pp. 53-69.

Nyerere, J. (1968). Freedom and socialism: a selection from writing and speeches, 1965-67. London: Oxford University Press. 
Nyerere, J. (1979). Education never ends. In H. Hinzen \& V.H. Hundsdorfer (Eds.), The Tanzanian experience: education for liberation and development. Hamburg: Evans Brothers.

Ozmon, H. \& Craver, S. (1998). Philosophical foundations of education. Toronto: Prentice Hall.

Rahnema, M. (1997). Introduction. In M. Rahnema \& V. Bowtree (Eds.), The post-development reader. London: Zed Books.

Rahnema, M. \& Bowtree, V. (1997). The post-development reader. London: Zed Books.

Rodney, W. (1974). How Europe underdeveloped Africa. Washington, DC: Howard University Press.

Rostow, W. (1991 [1960]). Stages of economic growth: a non-communist manifesto. Cambridge: Cambridge University Press.

Said, E. (1993). Cultural and imperialism. New York: Vintage.

Semali, L. (2009). Cultural perspectives in African adult education: indigenous ways of knowing in lifelong learning. In A. Abdi \& D. Kapoor (Eds.), Global perspectives on adult education. New York: Palgrave Macmillan, pp. 35-51.

Thomas, J. \& WOIO CBS19 Cleveland (2009). Fetus learns intonations of mother's tongue. http://www.bing.com/search?FORM=IEFM1\&q=fetus+learns. Retrieved on January 1, 2010.

Verhelst, T. (1991). No life without roots: culture and development. London: Zed Books.

wa Thiongo, N. (1986). Decolonising the mind: the politics of language in African literature. London: James Curry.

wa Thiongo, N. (1993). Moving the centre: the struggle for cultural freedoms. London: James Curry.

wa Thiongo, N. (2005). Europhone or African memory: the challenge of the pan-Africanist intellectual in the era of globalization. In T. Mkandawire (Ed.), African intellectuals: re-thinking politics, language, gender and development. London: Zed Books, pp. 155-164.

Ali Abdi is a Professor in the Department of Educational Policy Studies at the University of Alberta and was President of the CIESC from 2007-2009. He can be reached at aabdi@ualberta.ca. 